\title{
Differences in knowledge of oral health before and after counseling between lecture and role play method
}

\author{
Rini Yufita Sari*, Eka Chemiawan*, Nandang Sudarsana* \\ *Departement of Pedodontics Faculty of Dentistry Universitas Padjadjaran
}

\begin{abstract}
Introduction: Oral health education is one way to increase understanding in maintaining oral health. This will be effective if started at an early age. The purpose of this study is to analyzed differences in knowledge before and after counseling between lectures and play methods. Methods: Quasi experimental methods are used in this study. Samples were selected through purposive sampling, 27 sixth grade students and 12 elementary school students from Cikawao village were taken as sample. Questionnaires before and after counseling are used to address the differences in the knowledge of each student. Group 1 was given counseling on oral health through the lecture method while group 2 through the play method. Results: The study found that the increase in the mean score of the play method (6.53) was higher than the lecture method (4.75). The difference in knowledge after counseling between the lecture and play methods was significant among elementary school students. Conclusion: There are differences in oral health knowledge before and after counseling between the lecture method and the play method. The knowledge obtain after counseling with play methods is better when compared to lecture method.
\end{abstract}

Keywords: Counseling, method, lecturing, role playing.

\section{INTRODUCTION}

Oral health in Indonesia still requires very serious attention, especially the problem related to caries and periodontal disease. The efforts to overcome it until this day haven't showed any satisfactory results, thus the most effective promotive and preventive efforts to achieve optimal health efforts must be made.

Promotive and preventive efforts can be done through oral health education to the public. ${ }^{1}$ Oral health education can be done through counseling activities aimed at providing knowledge to the public so that those who do not know become know and understand. Efforts in counseling and maintaining oral health are effective if they start at the age of children, which is the ideal time to learn motor skills. Children are more receptive to and learn new skills. ${ }^{2}$ Oral health counseling is mostly done in elementary school children because at this age children can react to intellectual stimulation or carry out learning tasks. At that age the child's interest is devoted to everything that is dynamically moving and focused on a variety of activities.

The more they do, the more useful the activity is for the development of their personality. Oral health counseling to children will be more successful if carried out based on the learning and play process because in it there are a variety of 
dynamic activities. ${ }^{3}$ There are several types of counseling, but the most commonly used is oral health counseling with lecture and play methods. The journal Influence of Play Methods on Teaching and Oral Health, counseling with play methods has better effect compare to lecture methods. ${ }^{4}$

Counseling with the lecture method has several advantages besides being economical and easy to carry out, it can also be participated in by a large number of participants, but the lecture method that has often been used in counseling does not involve the participation, creativity and imagination of children so it tends to be one-way and if too long time will be boring.

This is why children are less interested in this method. ${ }^{5}$ Instead the game can cross various ages and can affect the appearance of children in public become more comfortable so that this can help in the process of oral health counseling. Cohen San Brandley also stated that the more active the learning process, the more fun when combined with playing. Therefore, the learning process will be more influential in increasing knowledge when combined with play methods. However, counseling with this method has not been widely used as it requires longer time and greater costs. ${ }^{5}$

Conducted research on the effect of play methods on oral health counseling, it stated that there was a difference between counseling with play and lecture. ${ }^{6}$ The results showed that the average statistical data on counseling with play method (1.7838) was higher than counseling with lecture method $(0.4211)$, thus concluded that oral health exposure with playing method was better than health education. ${ }^{7}$ This study uses a game of anyone who dares to try, draws balloon, and telephone game, so that the children know the importance of absorbing information properly and can is able to convey information appropriately. ${ }^{8}$

In addition, the procedure is easy to understand and does not require a long time. Children's health is a shared responsibility between parents from the family environment and teachers as parents from the school environment. Teachers at Cikawao Public Elementary School are aware of this, therefore the school has paid attention to the student's health in carrying out school activities, one of which is by establishing a School Health Efforts (UKS) program. However, the elementary school does not given special attention to this program. In addition, it is located far from urban areas so that it does not get the attention of the local government. The authors are interested in conducting research on differences in knowledge before and after counseling between the lecture method and the play method for Cikawao Elementary School students. The purpose of this study was to determine differences in oral health knowledge before and after counseling between lecture methods and play methods.

\section{METHODS}

This study is quasi-experimental based which aims to obtain information that is an estimate for information that can be obtained by actual experiments in circumstances that do not allow to control or manipulate all relevant variables. ${ }^{8}$ The students from Cikawao Public Elementary School (Sukawangi Village, Pamovery District, Sumedang Regency) were choose as the study population. The sample for this study was taken using a purposive sampling technique, a sampling technique based on individual criteria or considerations or the consideration of researchers. ${ }^{9}$

The criteria of the population are choose from class IV and V students, those who able to read and write, with good general health condition and willing to participate in research. A total of 27 sixth grade students and 12 Cikawao Elementary School students participated in this study. Questionnaires before and after counseling are used to address differences in the knowledge of each student. Group 1 was given oral health counseling through the lecture method while group 2 through the play method. The questionnaire consisted of 15 questions that had tested for validity and reliability.

\section{RESULTS}

Lecture method before counseling the lowest value is 1 , while for the highest value is 10 . After counseling, it shows increase in value, with the lowest value is 6 and the highest value is 14 . The average value before counseling with the method lecture is 5,10 and after counseling there is an increase in the average value to 9,85 . The value of tcount in table 1 (11.78) are greater than table 2 
(2.09). The error of rate tolerance (a) in this study was $5 \%$. The results of the paired " $\mathrm{t}$ " statistical test are shown in table 1 and the results of the correct value of the questionnaire in the lecture method are shown in graph 1 below.

Table 1. T-test results paired with differences in knowledge before and after counseling on the lecture method

\begin{tabular}{ccccc}
\hline $\begin{array}{c}\text { Paired Sample } \\
\text { Test }\end{array}$ & $\begin{array}{c}\text { Selisih Data } \\
\text { Pair }\end{array}$ & Test results \\
\hline $\begin{array}{c}\text { Difference of } \\
\text { knowledge } \\
\text { before and after } \\
\text { counseling the } \\
\text { lecture method }\end{array}$ & $\overline{\mathrm{B}}$ & & $\mathrm{Sb}$ & \\
\hline & 4,75 & 1,80 & 11,78 & $\mathrm{H}_{0}$ rejected \\
\hline
\end{tabular}

Graph 1. Values before and after counseling on the lecture method

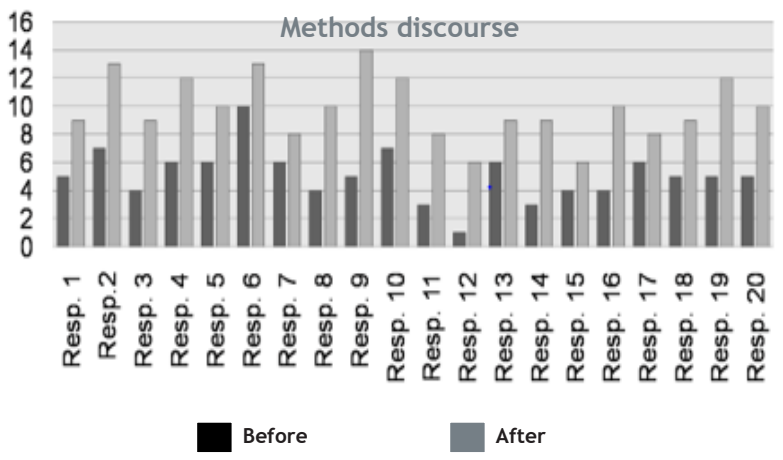

Table 2. T-test results paired with differences in knowledge before and after counseling using play methods

\begin{tabular}{clccc}
\hline $\begin{array}{c}\text { Paired Sample } \\
\text { Test }\end{array}$ & $\begin{array}{l}\text { Pairwise } \\
\text { Data Dif- } \\
\text { ference }\end{array}$ & $t_{\text {hitung }}$ & $t_{\text {tabel }}$ & $\begin{array}{c}\text { Test } \\
\text { results }\end{array}$ \\
\hline
\end{tabular}

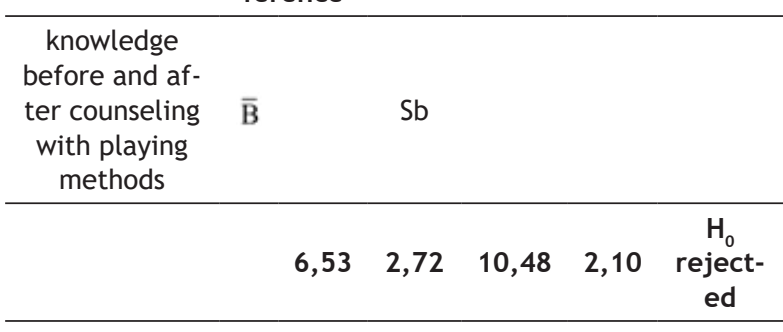

Table 2 obtained the value of tcount (10.48) is greater than table (2.10). The error rate tolerated (a) in this study is $5 \%$. The results of the paired " $t$ " statistical test are shown in table 2 and the results of the correct value of the questionnaire on the play method are shown in graph 2 below.

Table 3 shows the value of tcount (2.42) is greater than the value of ttable (2.03). This shows that there are differences in knowledge before and after counseling between the lecture method and the play method for Cikawao Elementary School students. Based on the average value of knowledge
Graph 2. Values before and after counseling on the playing method

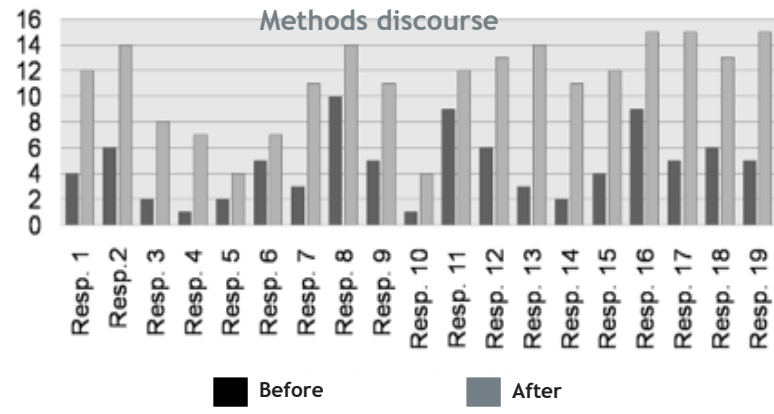

change, the play method (6.53) is greater than the lecture method (4.75), this shows that the play method is more effective in increasing students' knowledge when compared with the lecture method. The error of rate tolerace $(\alpha)$ in this study is $5 \%$. The results of the independent " $t$ " statistical test are shown in table 3 and the results of the change in the questionnaire values in the lecture method and play method are shown in graph 3 below.

Table 3. T-test results are independent of differences in knowledge after counseling between the lecture method and the play method

\begin{tabular}{ccccc}
\hline $\begin{array}{c}\text { Independent } \\
\text { Test Sample }\end{array}$ & Assumption & t-hitung & t-tabe & $\begin{array}{c}\text { Test } \\
\text { results }\end{array}$ \\
\hline $\begin{array}{c}\text { Differences } \\
\text { in knowledge }\end{array}$ & $\begin{array}{c}\text { The second } \\
\text { after counsel- } \\
\text { variance of }\end{array}$ & & & \\
$\begin{array}{c}\text { ing between } \\
\text { lecture meth- } \\
\text { the sample } \\
\text { is homoge- } \\
\text { methods }\end{array}$ & $\begin{array}{c}\text { neous } \\
\text { metay }\end{array}$ & & 2,03 & $\begin{array}{c}\mathrm{H}_{0} \\
\text { rejected }\end{array}$ \\
\hline
\end{tabular}

Graph 3. Changes in value between the lecture method and the plav method

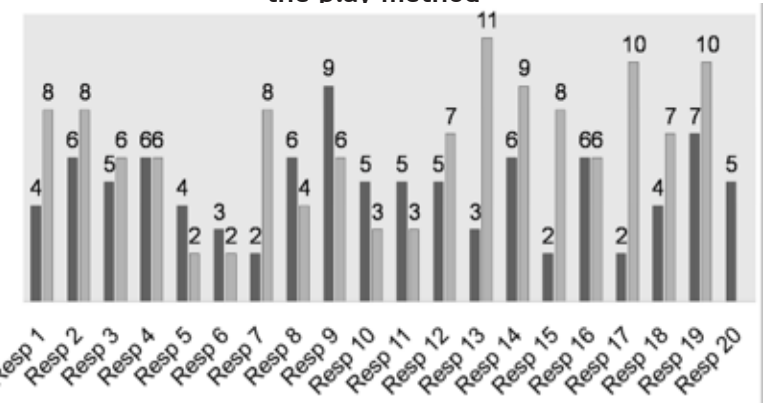

\section{DISCUSSION}

Based on Table 1, tcount (11.78) is greater than ttable (2.09). This shows that there is a significant difference in knowledge between before and after counseling on the lecture method of Cikawao Elementary School students. Thus, the lecture 
method is more effective in increasing students' knowledge about oral health. Since the counseling is carried out in the classroom, the participants could listen to counseling well. The classroom atmosphere is calm and the instructor delivers the material well and clearly. Counseling is delivered verbally by using extension tools in the form of flipcharts and dental models that help participants in understanding the material and accompanied by questions and answers so that participants become more understanding and understanding.

Meanwhile in the play method before counseling, the lowest value is 1 and the highest value is 10 . After counseling, the value had increased, with 4 as the lowest value and 15 as the highest value. The average value before counseling with playing method is 4.63 and after counseling there is an increase in the average value to be. ${ }^{10,11}$

Based on Table 2, the value of tcount (10.48) is greater than table 2 . This shows that there is a significant difference in knowledge between before and after counseling using the playing method of Cikawao Elementary School students. This means counseling with effective play methods in increasing students' knowledge about oral health.

Play method is carried out under a shady tree in the school yard which gives a more relaxed atmosphere, although in practice there are disturbances as some students who are not participants participating in the counseling process but it is not very influential because the extension participants remain enthusiastic and focused in following the game. Counseling material is delivered by playing which gives pleasure, information, and even imagination and involves a lot of children's participation, so that the material is delivered and can be well received. This has resulted in a significant increase in student knowledge.

T-independent statistical tests were conducted to test the differences in the success rates of each method before and after counseling. To find out the difference in knowledge between the lecture method and the play method is obtained from the change in the value of each method, it can be seen that the lowest value changes in the lecture method is 2 and the highest change in value is 9 with an average of 4.75 while in the method play seen the lowest value change is 2 and the highest value change is 11 with an average of 6.53 .

The atmosphere in play methods is more active, fun and involves a lot of student participation so that participants can receive the material well and keep concentrating and follow counseling activities from beginning to end. Jerome Singer revealed that games are used by children to explore their world and develop children's creativity, so that children will be able to create information from their play activities. ${ }^{9}$

Note that, even though the delivery of material is more fun with the atmosphere of play in activities, the children are more prone to forget the material presented because children are too forces in playing. Many games involve children's movement activities that can be defeated and make them become less focused on the material. revealed that the lecture delivering method was more passive in nature and involved fewer participants.

The lecture method if delivered in a long time tends to be boring which reduced the concentration and focused of the children from the beginning to the end of counseling, participants are enthusiastic at the beginning of counseling while for the next time their concentration is reduced and no longer feel interested in participating in counseling, it also causes the low questionnaire value. Thus, the average value of the lecture method is smaller when compared to the play method.

\section{DISCUSSION}

There are differences in oral health knowledge before and after counseling between the lecture method and the play method. The knowledge obtain after counseling with play methods is better when compared to lecture method.

\section{CONCLUSION}

In a conclusion, there are differences in oral health knowledge before and after counseling between the lecture method and the play method. The knowledge obtain after counseling with play methods is better when compared to lecture method. 


\section{REFERENCES}

1. Herijulainti E. Pendidikan Kesehatan Gigi. Jakarta: EGC. 2002. 63-85 pp.

2. Hurlock BE. Perkembangan Anak. $6^{\text {th }}$ Ed. Jakarta: Erlangga. 1988. 149-162 pp.

3. Kartono, Kartini. Psikologi Anak. Bandung: Mandar maju. 2007. 116-144 pp.

4. Budiharto. Kontribusi umur, pendidikan, jumlah anak, status ekonomi keluarga, pemanfaatan fasilitas kesehatan gigi dan pendidikan kesehatan gigi terhadap perilaku ibu. J Ked UI. 1998;5(2):99-108

5. Adrian. Metode Mengajar Berdasarkan Tipologi Belajar Siswa. 2004.

6. Rusly, Mieske, Gondhoyoewono T. Pengaruh Metode Bermain terhadap Penyuluhan
Kesehatan Gigi dan Mulut. 2009.

7. Rusly, Mieske, Gondhoyoewono T. Pengaruh Metode Bermain terhadap Penyuluhan Kesehatan Gigi dan Mulut. 2009.

8. Muhamad R. Games For Islamic Mentoring. Bandung: Syaamil Cipta Media. 2007. 49 pp.

9. Sumadi S. Metodologi Penelitian. Jakarta : Rajawali Pers. 2009. 92 pp.

10. Sudjana. Metode Statistika. $6^{\text {th }}$ Ed. Bandung: Tarsisto. 1996. 161-468 pp.

11. Roma P. Penggunaan Metode Bermain dalam Meningkatkan Hasil Belajar Siswa pada Perkalian Kelas III A SD Negeri No. 106159 Sampali. 2009

12. Syah M. Psikologi Pendidikan Dengan Pendekatan Baru. Bandung: Remaja Rosdakarya. 2000. 280 pp. 